\title{
Fuchs' heterochromic cyclitis: review of the literature on the pathogenetic mechanisms
}

\author{
E La Hey, P T V M de Jong, A Kijlstra
}

\section{Fuchs' theory}

Ernst Fuchs, who first described this disease in 1906, assumed that the syndrome was caused by a noxious factor of unknown origin, which was active from fetal or early postnatal life.' First, the normal development of uveal pigmentation would be inhibited, resulting in heterochromia (Fig 1). Later, the eye would respond to this pathological agent by a low grade inflammation. Many objections were raised against Fuchs' theory. The heterochromia was not always congenital and there were no signs of overt ocular inflammation.

\section{Sympathetic theories}

The sympathetic theories are based on the fact that sympathetic lesions may be followed by iris hypochromia. Bistis introduced the idea that some 'trophic' defect in the sympathetic nerve system inhibited the normal process of uveal pigmentation. ${ }^{23}$

Two other conditions have also been associated with Fuchs' heterochromic cyclitis (FHC) and a sympathetic defect - 'status dysraphicus' and progressive facial hemiatrophy (Parry Romberg syndrome). ${ }^{245}$ 'Status dysraphicus' was described as a microform of syringomyelia, which was believed to be due to a faulty closure of the primitive neural tube. Sometimes FHC was its sole manifestation. ${ }^{2}$ Other abnormalities frequently reported to be part of 'status dysraphicus' were ${ }^{678}$ : (1) Marfan syndrome and the Parry Romberg syndrome; (2) skeletal abnormalities, such as kyphoscoliosis and 'funnel chest'; (3) Horner's syndrome, pigment asymmetry of the nipples; (4) sensory and motor neuron disturbances, such as acrocyanosis, involvement of the fifth, sixth, and seventh cranial nerves.

In 1973, Loewenfeld and Thompson ${ }^{2}$ rejected the sympathetic theory. In their literature review of 1746 cases with FHC, only 25 cases (1.4\%) with FHC and Horner's syndrome were found. This was said to be too low an incidence to indicate a relation between FHC and the occurrence of a sympathetic defect (Horner's syndrome). ${ }^{2}$ Loewenfeld and Thompson, however, did not compare this figure $(1 \cdot 4 \%)$ with the product of the prevalence of the separate diseases in the general population, which is necessary when a clinical (epidemiological) association is investigated. No evidence was found for the existence of 'trophic sympathetic nerve fibers' and it was proved that 'status dysraphicus' was a manufactured syndrome without existence in reality. ${ }^{2}$

However, since 1973, four more patients with FHC and the syndrome of Parry Romberg have been reported..$^{-11}$ In two other cases Horner's syndrome and FHC developed consecutively in the same eye after stellate ganglionectomy. ${ }^{1{ }^{13}}$ Five patients with unilateral FHC and ipsilateral Horner's syndrome were reported. ${ }^{14}$ Pupillary changes, Horner's syndrome, and heterochromia are often reported in patients with hemifacial atrophy, and are all signs of an impaired sympa- thetic nervous system. ${ }^{15}$ The leakage seen on the iris fluorescein angiographic studies in FHC may be caused by a disturbance in the iris vessel innervation, which is solely derived from the sympathetic nerve system. ${ }^{16-18}$ Electron microscopic studies in FHC have suggested that the hypochromia may result from a defective melanin production, caused by abnormal adrenergic innervation. ${ }^{19}$

Laties, ${ }^{2021}$ Ehinger, ${ }^{22}$ and others ${ }^{23-25}$ have demonstrated a direct adrenergic innervation of iris stromal melanocytes. For mammals this is extraordinary, because skin melanocytes have no innervation..$^{20} \mathrm{After}$ denervation of the sympathetic nervous system on one side in young rabbits ${ }^{20}$ a significant decrease in activity of the enzyme tyrosinase was found in the ipsilateral, discoloured iris tissue. Moss and Cirkelair demonstrated hemifacial atrophy after unilateral cervical sympathectomy in young rats. ${ }^{26}$ Evidence for a neurovascular defect involved in the pathogenesis of hemifacial atrophy was
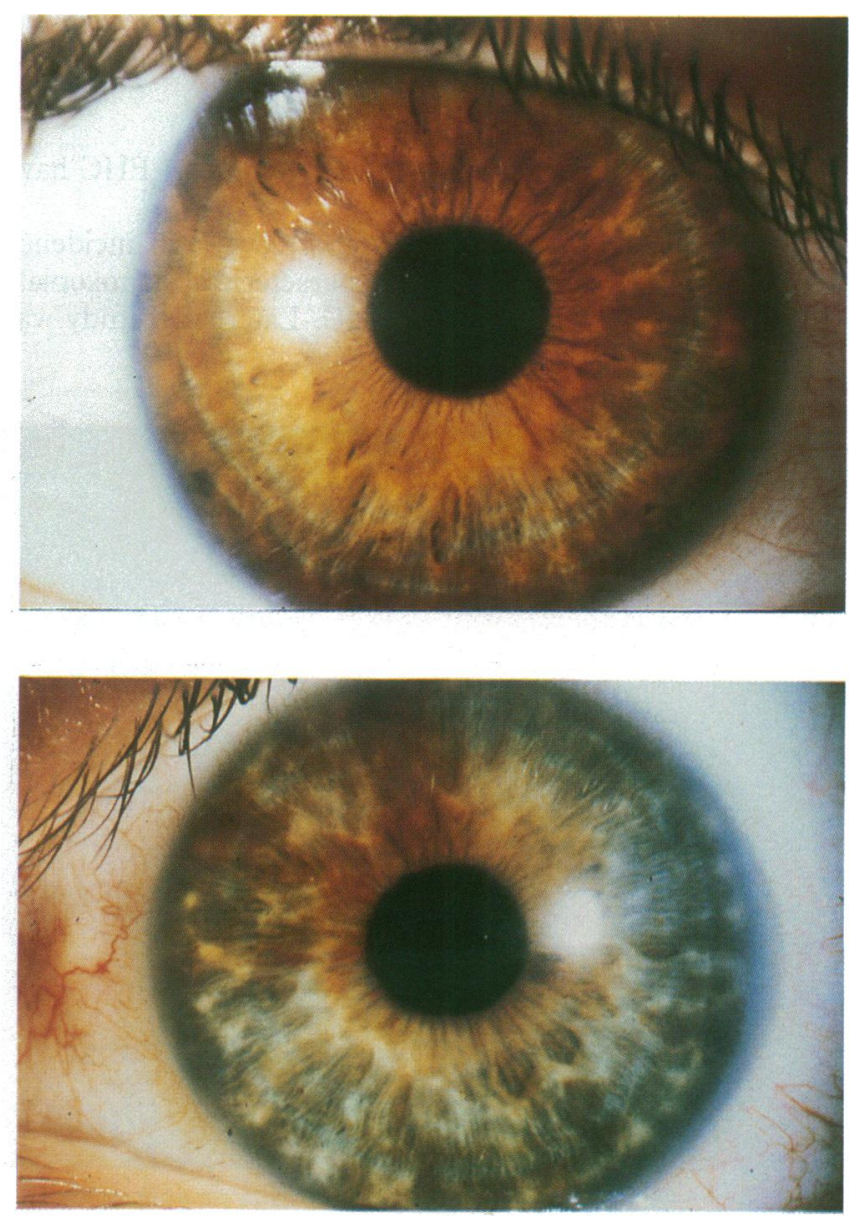

Figure 1 Eyes of a patient with Fuchs' heterochromic cyclitis. (A) Normal eye, $(B)$ cyclitic eye. 
found in a recent electron microscopic study on human skin biopsy specimens. ${ }^{22}$

The iris hypopigmentation in FHC and Horner's syndrome may be due to a common factor: a defective production of melanin granules caused by inadequate function of the adrenergic nerves. Furthermore, defective adrenergic innervation of blood vessels in FHC may cause increased permeability of the blood-aqueous barrier with subsequent leaking of proteins, cells, and inflammatory mediators into the aqueous.

\section{Hereditary theory}

Because two types of heterochromia are dominantly hereditary, namely 'simple' uncomplicated heterochromia and heterochromia in Waardenburg syndrome, it was thought that all types of heterochromia, including FHC, were hereditary. ${ }^{2}$

In 1973, Loewenfeld and Thompson performed a review of 1500 cases with FHC and found only five families with two cases of FHC. ${ }^{2}$ Dernouchamps found six familial cases in the 550 cases with FHC described by members of the IUSG. ${ }^{28}$ The proportion of familial cases is thus very small and does not provide adequate proof for the hereditary theory in FHC. In 1956, Makley ${ }^{29}$ described monozygotic twins who both developed FHC. Recently, another pair of monozygotic twins was reported, of which only one child had FHC. ${ }^{30}$ Studies on HLA typing in patients with FHC have shown no significant deviation in the distribution of HLA-A or B antigens in FHC compared with normal healthy blood donors. ${ }^{31}{ }^{32}$ The frequency of HLA-CW3 and HLA-DRW53 was, however, decreased in patients with FHC compared with healthy controls and a possible role for HLA-linked genetic factors in the pathogenesis was suggested..$^{32}$ Further reports with larger series of patients are necessary to confirm this assumption.

\section{Association with ocular toxoplasmosis}

Three theories explaining the fundus lesions in FHC have thus far been proposed.

(1) In 1982, de Abreu et $a l^{33}$ reported a high inçidence $(56.5 \%)$ of chorioretinal lesions characteristic of toxoplasmosis in their 23 patients with FHC. Later, this study was

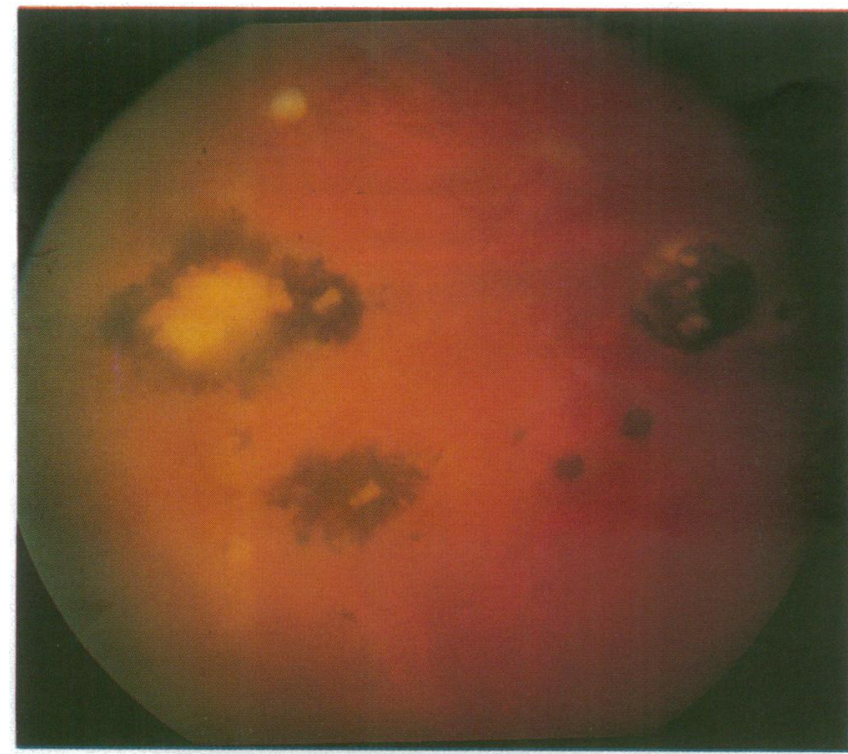

Figure 2 Fundus lesions were defined as characteristic for toxoplasmosis if they were one to three disc diameters in size, with a white centre and hyperpigmented borders, and flat or depressed. This patient with unilateral Fuchs' heterochromic cyclitis had such lesions in the ipsilateral eye. confirmed by other authors. ${ }^{34-38}$ It was suggested that these fundus lesions were caused by a (previous) Toxoplasma gondii infection. ${ }^{33}$ Until now, only few patients with FHC and active Toxoplasma retinochoroiditis have been described, ${ }^{33-35373940}$ who truly support the association between FHC and ocular toxoplasmosis.

The reported prevalence of toxoplasmosis-like lesions in FHC varies considerably between the studies: $7 \cdot 5$ to $65 \% . .^{33-38}$ This may be due to the fact that lesions in the peripheral retina are often missed in studies based on retrospective analysis. Furthermore, not all authors used the same criteria and some authors ${ }^{35}$ did not even mention their definition of a 'toxoplasmosis-like' chorioretinal scar (Fig 2). Another explanation may be that the prevalence of Toxoplasma retinochoroiditis differs between populations $\mathrm{s}^{41}$ as shown by a difference in prevalence of antibodies against Toxoplasma

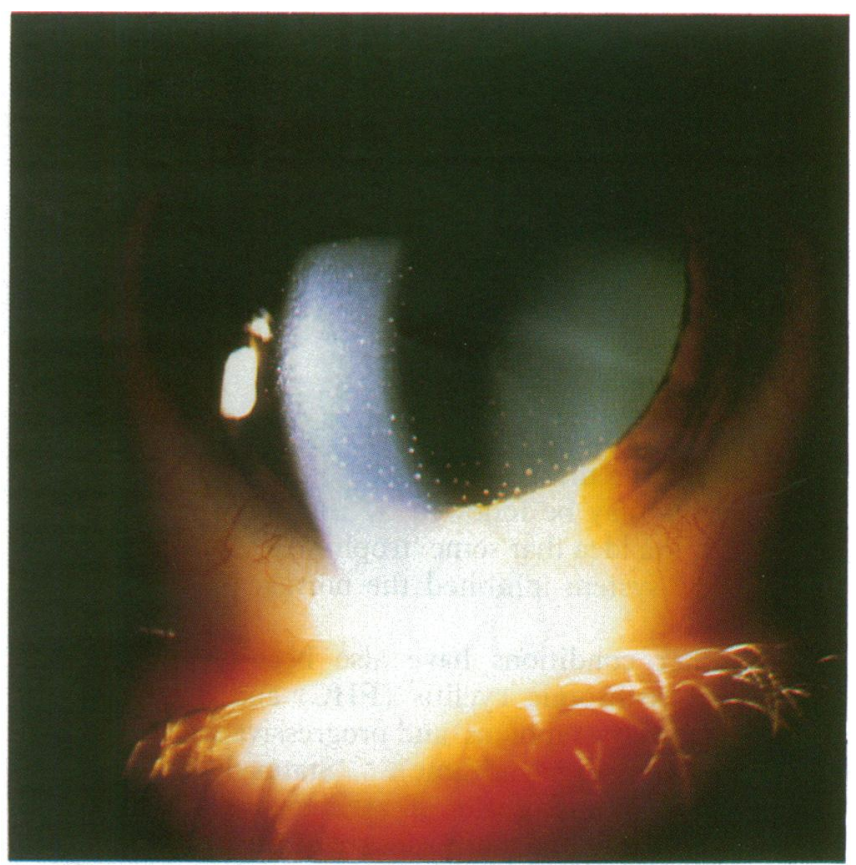

Fig $3 A$

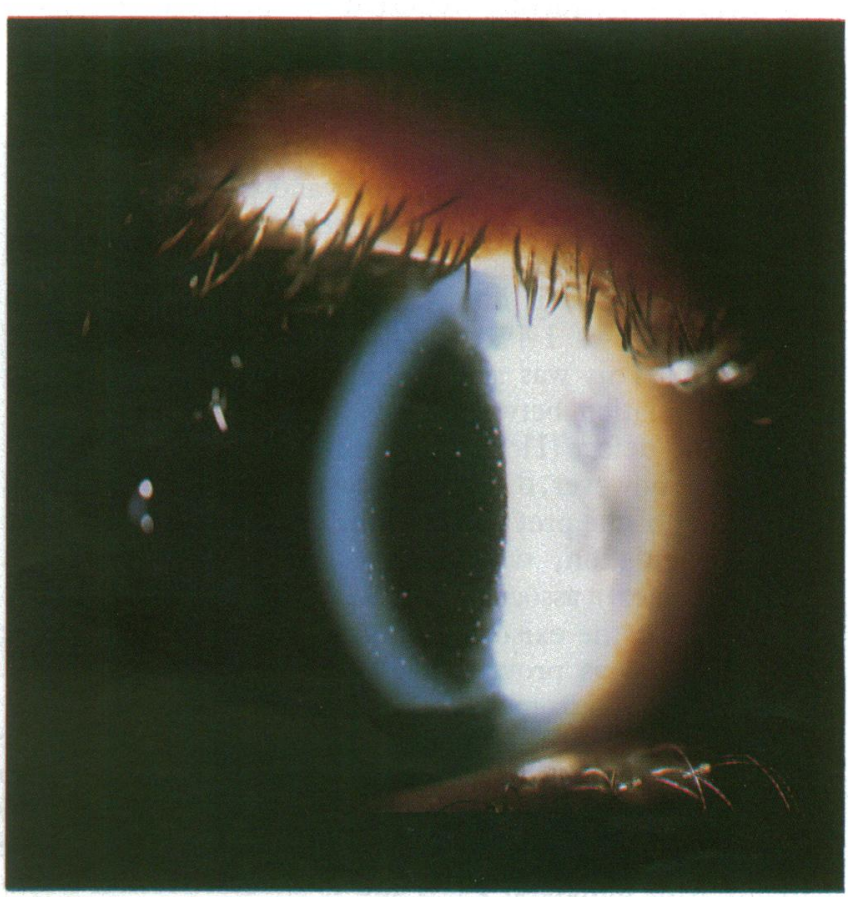

Fig $3 B$

Figure 3 ( $A$ and $B$ ) Characteristic small translucent keratic precipitates scattered on the entire endothelium. 
gondii. ${ }^{42+4}$ Moreover, Toxoplasma gondii strains may vary in their virulence. ${ }^{45}$ Therefore, it is important that a control group from the same population is studied simultaneously. This was done in four studies. ${ }^{34}{ }^{36-38}$ A significantly higher percentage of patients with FHC had chorioretinal scars consistent with ocular toxoplasmosis than these control groups.

In a recent study, ${ }^{38}$ the association between FHC and toxoplasmosis-like scars could not be substantiated by laboratory tests for toxoplasmosis. ${ }^{38}$ No active chorioretinal lesions, however, were present in the patients with FHC at the time of sampling..$^{38}$ Moreover, Toxoplasma serology has no definite diagnostic value for ocular toxoplasmosis, since in the general population a high prevalence of positive titres also exists. In addition, even in children with definite ocular toxoplasmosis a negative Sabin-Feldman dye test was sometimes encountered.

(2) Schwab ${ }^{34}$ recently reported that in five of his 16 patients with FHC and toxoplasmosis-like lesions the typical corneal precipitates (Fig 3) were absent. Patients with ocular toxoplasmosis sometimes have clinical findings closely resembling those of FHC..$^{34}{ }^{37}$ Schwab therefore suggested that ocular toxoplasmosis can create a chronic condition that can resemble FHC, but not have the same pathogenesis. ${ }^{34}$ This idea needs further investigation.

(3) In addition to toxoplasmosis-like scars, non-specific chorioretinal scars and histoplasmosis-like scars were found in patients with FHC. ${ }^{36-3847}$ Arffa and Schlaegel ${ }^{36}$ described two patients with $\mathrm{FHC}$ who had fundus lesions characteristic of toxoplasmosis, but negative titres for toxoplasmosis in undiluted serum. They suggested that the chorioretinal lesions could result from autoimmunity against retinal or choroidal antigens. ${ }^{36}$ In support of this hypothesis, La Hey et $a l^{48}$ found that a significantly higher percentage of patients with FHC had a positive cellular autoimmune response to human retinal $\mathrm{S}$ antigen than healthy controls or other patients with anterior uveitis. However, no chorioretinal scars were seen in five out of six cases of FHC with a positive immune response to $S$ antigen. ${ }^{48}$ Probably the immune sensitisation against $S$ antigen in these patients is a secondary autoimmune (epi-) phenomenon and does not cause the chorioretinal lesions. Recently, the presence of messenger RNA (mRNA) of $S$ antigen was demonstrated in irides obtained from patients with uveitis but not from control irides. ${ }^{49}$ This finding may indicate a possible role for $S$ antigen in anterior segment inflammation and could account for the fact that some patients with FHC without chorioretinal scars had a positive cellular immune response to $S$ antigen.

\section{Vascular theory}

The first vascular abnormality described in patients with FHC was the characteristic filiform haemorrhage (Amsler's sign) seen after anterior chamber paracentesis. ${ }^{50}$ Later, iris fluorescein angiographic studies ${ }^{16-18}$ showed leakage from iris vessels and areas of ischaemia, associated with neovascularisation. Earlier, light microscopic studies had shown abnormal hyalinisation of the iris vessel walls, with narrowing of the vessel lumen. ${ }^{1651-53}$

It was suggested that an immune complex vasculitis caused the vascular abnormalities in the iris. ${ }^{4}$ This was based on the detection of circulating immune complexes in the aqueous humour and serum of patients with FHC. ${ }^{5455}$ However, an unusual technique to detect these immune complexes was used. ${ }^{54}$ It is therefore necessary to confirm these findings with standard immune complex assays.

Patients with FHC are generally free of the more commonly encountered systemic manifestations of immune complex vasculitis, such as arthritis, glomerulonephritis, or scleritis. Moreover, FHC is usually a unilateral disease.
Thus, it seems more likely that intraocular factors may be responsible for the local formation of immune complexes in the iris vessel wall. As suggested by O'Connor, ${ }^{51}$ plasma cells demonstrated in the iris ${ }^{1291-535657}$ may somehow escape the normally imposed regulation by $\mathrm{T}$ lymphocytes. An intraocular 'B cell factory' may result, which produces a large amount of immunoglobulins and low affinity antibodies with subsequent intraocular immune complex formation. ${ }^{5155}$

Recently, deposits of immunoglobulins and complement, indicating the presence of immune complexes, were found in the vessel walls of the iris from patients with FHC. ${ }^{58}$ However, no light microscopic evidence for an inflammatory vascular process could be detected. ${ }^{58}$ These immune deposits were also found in other types of uveitis, but not in the irides of patients with glaucoma without uveitis. Further studies are necessary to determine the pathogenetic role of these immune deposits and to find out whether they result from local formation or originate from the circulation.

\section{Immunological theory}

The hypothesis that a degradation of uveal tissue following an infection would cause an autoimmune reaction against this (altered) tissue, was one of the earliest immunological theories. It was based on the finding of anti-uvea autoantibodies at high concentrations in the aqueous humour of patients with FHC. ${ }^{59}$ In a more recent study, however, no autoantibodies against human iris tissue could be demonstrated in any of the serum samples obtained from 27 patients with FHC. ${ }^{60}$

In 1960, an increased level of the gammaglobulin fraction, which later appeared as a relative excess of IgG, was found in the aqueous humour of patients with FHC. ${ }^{61}{ }^{62}$ Murray et $a l^{63}$ confirmed these findings of intraocular IgG production. He also demonstrated oligoclonal IgG bands, mainly of the IgG1 subclass, in the aqueous humour of $57 \%$ of his patients with FHC. No oligoclonal IgG response was found in the aqueous humour of other patients with uveitis. Furthermore, Murray et al demonstrated a local production of the cytokine interleukin 6 (IL-6), in the aqueous humour of $63 \%$ of the patients with FHC, but also in $70 \%$ of the other types of uveitis. ${ }^{64}$

In a recent immunohistochemical study ${ }^{57}$ interleukin 2 receptor negative $\mathrm{T}$ helper and $\mathrm{T}$ suppressor lymphocytes, $\mathrm{B}$ lymphocytes, and plasma cells were demonstrated in four out of eight irides from patients with FHC. Similar findings, however, were also observed in patients with other types of uveitis.

Seventy per cent of all patients with FHC showed a cellular autoimmune response against a major corneal antigen (54 $\mathrm{kDa}$; aldehyde dehydrogenase). ${ }^{65}$ Autoantibodies against corneal epithelium were recently demonstrated in almost $90 \%$ of the patients with FHC. ${ }^{60}$

No abnormalities have been detected in any of the following immunological parameters in the peripheral blood of patients with FHC: immunoglobulin $\mathrm{G}, \operatorname{IgA}, \operatorname{Ig} M$, rheumatoid factor, $\mathrm{C}$ reactive protein, antinuclear antibodies, antismooth muscle antibodies, antigastric parietal cell antibodies, antilens antibodies, total lymphocyte count, total number of T cells, number of helper or suppressor T cells, or soluble serum ICAM-1, a circulating adhesion molecule. ${ }^{5566-68}$

\section{Authors' hypothesis}

FHC (Fig 4) seems a complex disease with various clinical features and multiple causes. The high incidence of cellular immunity ${ }^{65}$ and humoral immunity ${ }^{60}$ against corneal antigens may be associated with the typical keratic precipitates. It is tempting to speculate that the diffuse scattering of these keratic precipitates on the corneal endothelium in FHC represents (cellular) immune responses to (a) corneal anti- 


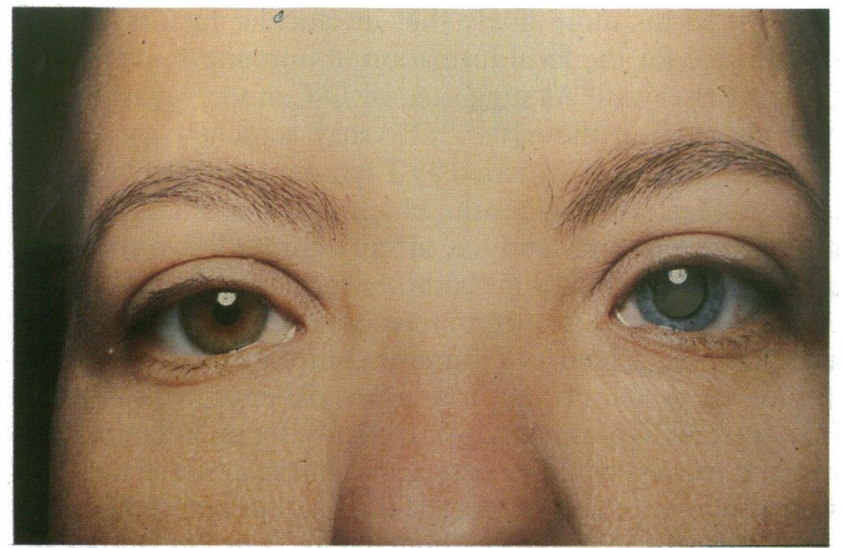

Figure 4 Patient with Fuchs' heterochromic cyclitis and cataract of the left eye.

gen(s), in comparison with the usually inferior distribution of keratic precipitates in other forms of anterior uveitis. Indeed, as reported by Foets, ${ }^{69} 70$ human corneal endothelial cells should be considered as 'active' immunomodulating cells because of their ability to express MHC class II antigens and immune adhesion molecules. The sensitisation against retinal $\mathrm{S}$ antigen found in patients with $\mathrm{FHC}^{48}$ is even more conspicuous. Arrocker ${ }^{71}$ and Murray $^{72}$ independently demonstrated that a high proportion of patients with FHC had an increased level of interleukin 2 receptor (IL-2R), a marker of (T) lymphocytic activation. Such a high incidence of cellular autoimmunity against various ocular antigens is remarkable.

One has to keep in mind that the eye is an immunologically privileged site, as shown by the ACAID (anterior chamber associated immune deviation) phenomenon: when soluble antigens are placed within the anterior chamber, a systemic antigen specific inhibition of delayed type hypersensitivity (DTH) to this antigen occurs. ${ }^{73}$ Also within the anterior chamber itself, expression of cell mediated immunity of
DTH is strongly inhibited. ${ }^{74} 75$ The aqueous humour in normal eyes seems to be a powerful inhibitor of certain aspects of antigen driven $T$ cell function, a capacity which may be largely conferred by the cytokine transforming growth factor $\beta$ (TGF- $\beta$ ) secreted by iris and ciliary body parenchymal cells, and the neuropeptides, $\alpha$-melanocyte stimulating hormone $(\alpha-\mathrm{MSH})$ and vasoactive intestinal peptide (VIP), produced by ocular neurons. ${ }^{7677}$ Intracameral injections of a subinflammatory dose of interferon $\gamma($ IFN- $\gamma)$, a cytokine that antagonises TGF- $\beta$, resulted in a disturbance of this immunosuppressive microenvironment and the development of severe intraocular inflammation. ${ }^{78}$

In FHC, this immunosuppressive mechanism (ACAID), may be diminished; the increased lymphocytic sensitisation found in these patients points in this direction. Perhaps the concentration of the immunosuppressive TGF- $B$ is decreased as a result of the atrophic process of the iris, also affecting the parenchymal cells.

Until now, also in studies using modern sensitive techniques, no specific (immuno-) histopathological abnormalities were found in the irides of patients with FHC. ${ }^{5758}$ The detection of oligoclonal IgG bands in the aqueous humour of these patients ${ }^{63}$ seems to be the only specific (immunological) abnormality detected until now. It may imply that a small number of intraocular B cells is stimulated by an (as yet unidentified) specific antigen, which may be part of an infectious agent or an intraocular autoantigen. This B cell stimulation may be the result of interleukin 6 (IL-6) production, demonstrated in the aqueous humour of patients with FHC. ${ }^{64}$

It was found that IL-6 significantly upregulated the expression of ICAM-1 on skin melanocytes, an adhesion molecule involved in the process of antigen presentation. ${ }^{79}$ Skin melanocytes have recently been shown to be capable of processing and presenting antigenic peptide fragments (after stimulation with IFN- $\gamma$ ) to cytotoxic $\mathrm{T}$ cell clones in an MHC-II restricted manner. ${ }^{80}$ Such melanocytes may thus

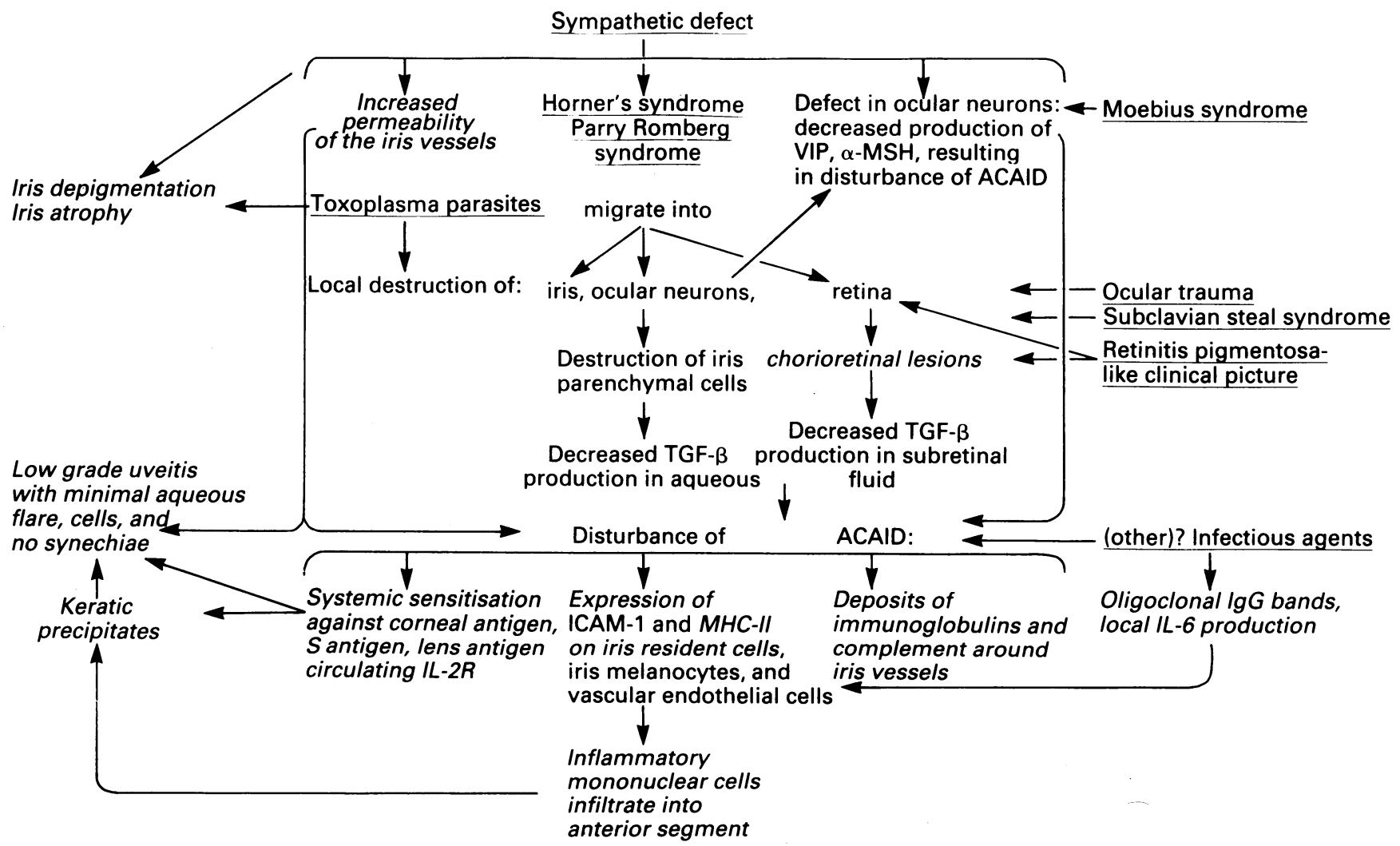

ear cells anterior segment

Figure 5 Schematic diagram of Fuchs' heterochromic cyclitis as secondary phenomenon. Underlined are the causes which may lead to Fuchs' heterochromic cyclitis. Clinical and (immuno)histopathological findings in this eye disease are in italic. All other findings and pathogenetic mechanisms in this diagram are hypothetical. 
function as target cells in $\mathrm{T}$ cell mediated (auto)immune reactions, leading to the destruction of these melanocytes with areas of depigmentation of the skin, as may be seen in vitiligo, a presumed autoimmune disease. ${ }^{80}$ Whether autoimmune reactions against melanocytes play a role in $\mathrm{FHC}$ has not yet been investigated.

Evidence accumulates that the iris hypopigmentation and increased vascular permeability of the iris vessels in FHC may be caused by inadequate function of adrenergic nerves. ${ }^{14} 16-192526$ Such an adrenergic defect may be congenital or it may be secondary to an inflammatory or autoimmune process of the iris. No autoantibodies against iris tissue, however, could be demonstrated in patients with FHC. ${ }^{60}$ The release of neuropeptides may be disturbed owing to a defect of the sympathetic nerve system. Subsequently, the function of (vascular) endothelial cells and the immunosuppressive microenvironment of the aqueous humour may be altered. Because the stromal melanocytes of the iris are derived from the neural crest, it is important to remark that TGF- $B$ has been suggested to play a crucial role in the differentiation of neural crest cells into the connective tissues of the eye during embryogenesis. ${ }^{81}$

Via a complex pathway of a secondary (auto)immune response, a congenital Toxoplasma gondii infection may be responsible for the secondary development of FHC in a small subset of patients. Nussenblatt ${ }^{82}$ suggested that the inflammatory retinal response in ocular toxoplasmosis is, at least in part, autoimmune. Also, in FHC a secondary autoimmune response may play a role. When a mother is infected during pregnancy, the neurotrophic Toxoplasma parasites may migrate into the retina. In utero, in patients with FHC, the Toxoplasma parasites may also have migrated into the iris. Toxoplasmal cysts have been found in the iris. ${ }^{83}$ By causing a local destruction of these tissues (iris, retina), a release of potent ocular antigens into the circulation may result, leading to a sensitisation against retinal (S) antigen(s) and/or iris antigens. A cellular autoimmune response to $S$ antigen could be demonstrated in patients with $\mathrm{FHC}^{+8}$ Whether a cellular immune response against iris antigens exists in patients with FHC has not been investigated. One can also imagine that if the Toxoplasma parasites have gained access to the iris during pregnancy, they may have altered the production of TGF- $\beta$ and the neuropeptides $\alpha-M S H$ and VIP, by a local destruction of the iris and ocular neurons. This may lead to a disturbance of the immunosuppressive properties of the aqueous humour (ACAID) and subsequently the development of an anterior uveitis. Indeed, recently TGF- $\beta$ was found to be decreased in experimental uveitis. ${ }^{84}$

In addition to toxoplasmosis, FHC has been reported in combination with a retinitis pigmentosa-like clinical picture ${ }^{85-87}$ ocular trauma, ${ }^{358}$ the subclavian steal syndrome, ${ }^{89}$ hemifacial atrophy, ${ }^{9-1190}$ Horner's syndrome, ${ }^{12-14}$ and Moebius syndrome. $^{91}$ The term FHC is merely descriptive; there is (still) no diagnostic test for this eye disease. Moreover, it is hardly likely that the clinical 'syndrome' of FHC has a single aetiology. Many pathogenetic mechanisms have been proposed, which all made sense in some aspects. FHC may have multiple causes. A number of different abnormalities may trigger the eye, which may have only a limited set of uveoretinal responses, to react in a particular (path)way, yielding the clinical end state of FHC. Such a stimulus may be immunological, infectious, or a combination of both. It may cause the release of potent autoantigens, leading to a common pathway of a secondary autoimmune uveitis that becomes self perpetuating. FHC is therefore probably a secondary phenomenon with a spectrum of clinical features and multiple causes (Fig 5).

Department of Ophthalmo-Immunology,

E LA HEY The Netherlands Ophthalmic Research Institute, Amsterdam
E LA HEY

Department of Ophthalmology,

P T V M DE JONG

Erasmus University

Rotterdam

Department of Ophthalmology,

University of Amsterdam,

The Netherlands

1 Fuchs E. Ueber komplikationen der heterochromie. Z Augenheilkd 1906; 15: 191-212.

2 Loewenfeld IE, Thompson HS. Fuchs' heterochromic cyclitis: a critical review of the literature. II. Aetiology and mechanism. Surv Ophthalmol 1973; 17: $2-61$.

3 Bistis J. La paralyse du sympathique dans l'etiologie de l'heterochromie. Arch Ophthalmol 1912; 9: 631-2.

4 Bremer F. Klinische untersuchungen zur aetiologie der syringomyelie und 'status dysraphicus'. Dtsch $Z$ Nervenheilkd 1926; 95: 1-103.

5 Passow A. Hornersyndrom, heterochromie und status dysraphicus, ein symptomenkomplex. Arch Augenheilkd 1933; 197: 1-51.

6 Franceschetti A. Heterochromic cyclitis. Am $\mathcal{F}$ Ophthalmol 1955; 39: 50-8.

7 Hollwich F. Zur differentialdiagnose der heterochromiezyklitis. Klin Monatsbl Augenheilkd 1963; 142: 129-39.

8 Hollwich F. Heterochromia complicata Fuchs'. Klin Monatsbl Augenheilkd 1988; 192: 87-96.

9 Jones NP. Fuchs' heterochromic uveitis: a reappraisal of the clinical spectrum. Eye 1991; 5: 649-61.

10 Fulmek R. Hemiatrophia progressiva faciei (Romberg-syndrome) mit gleichseitiger heterochromia complicata (Fuchs' syndrom). Klin Monatsbl gleichseitiger heterochromia comp
Augenheilkd 1974; 164: 615-28.

$11 \mathrm{La}$ Hey E, Baarsma GS. Fuchs' heterochromic cyclitis and retinal vascular abnormalities in progressive hemifacial atrophy. Eye 1993; 7: 426-8.

12 Calmettes ML, Deodati R, Amalric P. Un cas d'association d'heterochromie de Fuchs' et de syndrome de Claude Bernard Horner. Rev Oto-Neuro-Ophtalmol 1953; 25: 399-400.

13 Makley TA, Abbot K. Neurogenic heterochromia: report of an interesting case. Am f Ophthalmol 1965; 59: 927-8.

14 Regenbogen LS, Naveh-Floman N. Glaucoma in Fuchs' heterochromic cyclitis associated with congenital Horner's syndrome. $\mathrm{Br} \mathcal{F}$ Ophthalmol 1987; 71: $844-9$.

15 Hoang-Xuan T, Foster S, Jakobiec FA, Tauber J, de la Maza MS, Krebs W. Romberg's progressive hemifacial atrophy: an association with sclera melting. Cornea 1991; 10: 361-6.

16 Saari M, Vourre I, Nieminen H. Fuchs' heterochromic cyclitis. A simultaneous bilateral fluorescein angiographic study of the iris. Br $\mathcal{F} O$ phthalmol 1978; 62: $715-21$.

17 Bernsmeier H, Kluxen G, Friedburg D. Irisangiographische befunde bei heterochromia complicata Fuchs. Ber Disch Ophthalmol Ges 1981; 78: 49-51.

18 Berger BB, Tessler HH, Kottow MH. Anterior segment ischemia in Fuchs' heterochromic cyclitis. Arch Ophthalmol 1980; 98: 499-501.

19 Melamed S, Lahav M, Sandbank U, Yassur Y, Ben-Sira I. Fuchs' heterochromic iridocyclitis: an electron microscopic study of the iris. Invest Ophthalmol Vis Sci 1978; 17: 1193-9.

20 Laties AM, Lerner AB. Iris colour and relationship of tyrosinase activity to adrenergic innervation. Nature 1975; 225: 152-3.

21 Laties AM. Specific neurohistology comes of age: a look back and a look forward. Invest Ophthalmol Vis Sci 1972; 11: 555-84.

22 Ehinger $\mathrm{B}$. Adrenergic nerves to the eye and to related structures in man and in the cynomolgus monkey (Macaca irus). Invest Ophthalmol Vis Sci 1966; 5: $42-52$.

23 Ringvold A. An electron microscopic study of the iris stroma in monkey and rabbit with particular reference to intercellular contacts and sympathetic rabbit with particular reference to intercellular contacts and sym
innervation of anterior layer cells. Exp Eve Res 1975; 20: 349-65.

24 Opin L, O'Donnel FE. Adrenergic influence on iris stromal pigmentation: evidence for alpha-adrenergic receptors. Invest Ophthalmol Vis Sci 1982; 23: 528-30

25 Beckers HJM, Klooster J, Vrensen GFJM, Lamers WPMA. Sympathetic innervation of the rat's eye: an electron microscopic autoradiographic tracing study. Graefes Arch Clin Exp Ophthalmol (in press).

26 Moss ML, Cirkelair GJ. Progressive facial hemiatrophy following cervical sympathectomy in the rat. Arch Oral Biol 1960; 1: 254-8.

27 Pensler JM, Murphy GF, Mulliken JB. Clinical and ultrastructural studies of Romberg's hemifacial atrophy. Plast Reconstruct Surg 1990; 85: 669-74.

28 Dernouchamps JP. Fuchs' heterochromic cyclitis: an IUSG study about 550 cases. In: Saari KM, ed. Uveitis update. Amsterdam: Elsevier, 1984: 129-35.

29 Makley TA. Heterochromic cyclitis in identical twins. Am J Ophthalmol 1956; 41: 768-72.

30 Jones NP, Read AP. Is there a genetic basis for Fuchs' heterochromic uveitis? Discordance in monozygotic twins. Br F Ophthalmol 1992; 76: $22-4$.

31 Saari M, Vourre I, Pakarinen A, Tilikainen A. Immunological and immunogenetic studies on Fuchs' heterochromic cyclitis. In: Shimity K, Oosterhuis JA, eds. Concilium ophthalmologicum, Kyoto 1978. Int Congress series. Amsterdam: Excerpta Medica, 1978: 971-3.

32 De Bruyere M, Dernouchamps JP, Sokal G. HLA-antigens in Fuchs' heterochromic iridocyclitis. Am $\mathcal{F}$ Ophthalmol 1986; 102: 392-3.

33 De Abreu ML, Belfort R, Hirata PS. Fuchs' heterochromic cyclitis and ocular toxoplasmosis. Am $\mathcal{F}$ Ophthalmol 1982; 93: 739-44.

34 Schwab JR. The epidemiologic association of Fuchs' heterochromic iridocyclitis and ocular toxoplasmosis. Am $\mathcal{f}$ Ophthalmol 1991; 111: 356-62.

35 Saraux H, Laroche L, Le Hoang P. Secondary Fuchs's heterochromic cyclitis: a new approach to an old disease. Ophthalmologica 1985; 190: 193-8.

36 Arffa RC, Schlaegel TF. Chorioretinal scars in Fuchs' heterochromic iridocyclitis. Arch Ophthalmol 1984; 102: 1153-5.

37 Pezzi PP, Niutta A, Abdulaziz M, Paroli MP. Fuchs' heterochromic iridocyclitis and toxoplasmic retinochoroiditis. Int $\mathcal{f}$ Ophthalmol 1987; 1/2: 97-101.

38 La Hey E, Rothova A, Baarsma GS, de Vries J, van Knapen F, Kijlstra A. Fuchs' heterochromic cyclitis is not associated with ocular toxoplasmosis. Arch Ophthalmol 1992; 110: 806-11.

39 La Hey E, Rothova A. Fuchs' heterochromic cyclitis in congenital ocular toxoplasmosis. Brf Ophthalmol 1991; 6: 372-3. 
40 La Hey E, Baarsma GS. Contralateral active ocular toxoplasmosis in Fuchs' heterochromic cyclitis. Br $\mathcal{F}$ Ophthalmol 1993; 77: 455-6.

41 Henderly DE, Genstler AJ, Smith RE, Rao NA. Changing patterns of uveitis. Am f Ophthalmol 1987; 103: 131-7.

42 van der Veen J, Polak MF. Prevalence of toxoplasma antibodies according to age with comments on the risk of prenatal infection. 7 Hyg 1980; 85: 165-74.

43 Holland GN, Engstrom RE Ocular toxoplasmosis in the United States. In: Belfort R, Petrilli AMN, Nussenblatt R, eds. World uveitis symposium. Sao Paulo: Livraria Rocaltda, 1988: 315-22.

44 Glasner PD, Silveira C, Kruszon-Moran D, Martins MC, Burnier M, Silveira S, et al. An unusually high prevalence of ocular toxoplasmosis in Southern Brazil. Am 7 Ophthalmol 1992; 114: 136-44.

45 Sibley LD, Boothroyd JC. Virulent strains of Toxoplasma gondii comprise a single clonal lineage. Nature 1992; 359: 82-5.

46 Loewer-Sieger DH, Rothova A, Koppe JG, Kijlstra A. Congenital toxoplasmosis, a prospective study based on 1821 pregnant women. In: Saari $\mathrm{KM}$, ed. Uveitis update. Amsterdam: Elsevier, 1984;203-7.

47 Tabbut BR, Howard HT, Williams D. Fuchs' heterochromic iridocyclitis in blacks. Arch Ophthalmol 1988; 106: 1688-90.

48 La Hey E, Broersma L, van der Gaag R, Baarsma GS, Rothova A, Kijlstra A. Does S-antigen play a role in Fuchs' heterochromic cyclitis? Br 7 Ophthalmol 1993; 77: 436-9.

49 Chan CC, Li O, Kiuchi T, Shinohara T, Nussenblatt RB. Detection of the mRNA of S-antigen from irises of uveitic patients. Invest Ophthalmol Vis $S c i$ 1991; 32: 96 .

50 Amsler M, Verrey F. Heterochromie de Fuchs' et fragilite vasculaire. Ophthalmologica 1946; 111: 177-81.

51 O'Connor GR. Doyne lecture: heterochromic iridocyclitis. Trans Ophthalmol Soc UK 1985; 104: 219-31.

52 Goldberg MF, Erozan YS, Duke JR, Frost JK. Cytopathologic and histopathologic aspects of Fuchs' heterochromic iridocyclitis. Arch Ophthalmol 1965; 74: 604-9.

53 Wobman P. Die heterochromiecyclitis Fuchs'. Elektronenmikroskopische studie von 9 irisbiopsien. Graefes Klin Exp Ophthalmol 1976; 199: $167-78$

54 Dernouchamps JP, Vaerman JP, Michiels J, Masson P. Immune complexes in the aqueous humour and serum. Am $\mathcal{F}$ Ophthalmol 1977;24-31.

55 Murray PI Dinning WJ, Rahi AHS. Immune responses in heterochromic cyclitis. In: Secchi AG, Fregona J, eds. Modern trends in immunology and immunopathology of the eye. Milan: Mason Publishing, 1989; 295-7.

56 McCartney ACE, Bull TB, Spalton DJ. Fuchs' heterochromic cyclitis: an electron microscopy study. Trans Ophthalmol Soc UK 1986; 105: 324

57 Murray PI, Mooy CM, Visser-de Jong E, Baarsma GS, de Vries J, de Jong PTVM, et al. Immunohistochemical analysis of iris biopsy specimens from patients with Fuchs' heterochromic cyclitis. Am f Ophthalmol 1990; 109: $394-9$.

58 La Hey E, Mooy CM, Baarsma GS, de Vries J, de Jong PTVM, Kijlstra A. Immune deposits in iris biopsy specimens from patients with Fuchs' heterochromic iridocyclitis. Am f Ophthalmol 1992; 113: 75-80

59 Remky H. Auto-antigens, facteurs iridogenes de l'iritis. Bull Mem Soc Fr Ophtalmol 1965; 78: 401-11.

60 La Hey E, Baarsma GS, Rothova A, Broersma L, van der Gaag R, Kijlstra A. High incidence of corneal epithhelium antibodies in Fuchs' heterochromic cyclitis. Brf Ophthalmol 1988; 72: 921-5.

61 Francois J, Rabaey M. Microelectrophoresis on agar of normal and pathological aqueous humour. Arch Ophthalmol 1960; 63: 836-49.

62 Dernouchamps JP. The proteins of the aqueous humour. Doc Ophthalmol 1982; 53: 193-248.

63 Murray PI, Hoekzema R, Luyendijk L, Konings S, Kijlstra A. Analysis of aqueous humour immunoglobulin $\mathrm{G}$ in uveitis by enzyme-linked immunosorbent assay, isoelectric focusing, and immunoblotting. Invest Ophthalmol Vis Sci 1990; 31: 2129-35.

64 Murray PI, Hoekzema R, van Haren MAC, de Hon FD, Kijlstra A. Aqueous humour interleukin-6 levels in uveitis. Invest Ophthalmol Vis Sci 1990; 5: 917-20.

65 van der Gaag R, Broersma L, Rothova A, Baarsma GS, Kijlstra A. Immunity to a corneal antigen in Fuchs' heterochromic cyclitis patients. Invest Ophthalmol Vis Sci 1989; 30: 443-8.
66 Murray PI, Dinning WJ, Rahi AHS. T-lymphocyte subpopulations in uveitis. Br f Ophthalmol 1984; 68: 746-9.

67 Murray PI. Serum autoantibodies in uveitis. Br f Ophthalmol 1986; 70: 266-8

68 Arrocker-Mettinger E, Steurer-Georgiew L, Steurer M, Huber-Spitzy V, Hoezl E, Grabner G, et al. Circulating ICAM-1 levels in serum of uveitis patients. Curr Eye Res 1992; 11 (suppl): 161-6.

69 Foets BJJ, van den Oord JJ, Billiau A, van Damme J, Missotten L. Heterogeneous induction of MHC class II antigens on corneal endothelium by IFN- $\gamma$. Invest Ophthalmol Vis Sci 1991; 32: 341-5.

70 Foets BJJ, van den Oord JJ, Volpes R, Missotten L. In situ immunohistochemical analysis of cell adhesion molecules on human corneal endothelial cells. Br f Ophthalmol 1992; 76: 205-9.

71 Arocker-Mettinger E, Asenbauer T, Ulbrich S, Grabner G. Serum interleukin receptor levels in uveitis. Curr Eye Res 1990; 9 (suppl): $25-9$.

72 Murray PI, Young DW. Soluble interleukin-2 receptor in retinal vasculitis. Curr Eye Res 1992; 11 (suppl): 193-5.

73 Streilein JW, Niederkorn JY, Shadduck JA. Systemic immune unresponsive ness induced in adult mice by anterior chamber presentation of minor histocompatibility antigens. $\mathcal{F} \operatorname{Exp}$ Med $1980 ; 152$ : 1121-5.

74 Streilein JW. Immune regulation and the eye: a dangerous comprise. FASEB 1987; 1: 199-208.

75 Neiderkorn JY. Immune privilege and immune regulation in the eye. $A d v$ Immunol 1990; 48: 191-226.

76 Streilein JW, Wilbanks GA, Taylor A, Cousins SW. Eye-derived cytokines and the immunosuppressive intraocular micro-environment. A review. Curr Eve Res 1992; 11 (suppl): $41-7$.

77 Taylor AW, Streilein JW, Cousins SW. Neuropeptides contribute to the immunosuppressive activity of aqueous humour. Invest Ophthalmol Vis $\mathrm{Sc}$ 1993; 34: 903.

78 Cousins SW, Trattler WB, Streilein JW. Immune privilege and suppression of immunogenic inflammation in the anterior chamber of the eye. Curr Eve Res immunogenic inflam

79 Kirnbauer R, Charvat B, Schauer E, Kock A, Urbanski A, Forster E, et al. Modulation of intercellular adhesion-molecule-1 expression on human melanocytes and melanoma cells: evidence for a regulatory role of IL-6, IL-7, TNF-B and UVB light. F Invest Dermatol 1992; 98: 320-6.

80 Le Poole C, Mutis T, van den Wijngaard RMJGJ, Westerhof W, Ottenhof T, de Vries RRP, et al. A novel, antigen presenting function of melanocytes and its possible relation to hypopigmentary disorders. (Submitted for publication.)

81 Tripathi BJ, Tripathi RC, Livingston AM, Borisuth NSC. The role of growth actors in the embryogenesis and differentiation of the eye. Am 7 Ophthalmol 1991; 192: 442-71

82 Nussenblatt RB. Uveitis. In: Nussenblatt RB, Palestine AG, eds. Fundamental and clinical practice. Chicago: Year Book Medical Publishers, 1989.

83 Rehder JR, Burnier M, Pavesio CE, Kim MK, Riguiero M, Petrilli AM, et al. Acute unilateral toxoplasmic iridocyclitis in an AIDS patient. Am $\mathcal{F}$ Ophthalmol 1988; 106: 740-1.

84 Rocha G, Baines MG, Deschenes J, Duclos AJ, Antecka E. Transforming growth factor- $B$ levels in aqueous humour during experimentally induced uveitis. Ocular Immunol Inflam 1994 (in press)

85 Francois J, Mastilovic B. L'heterochromie de Fuchs' associee aux heredodegenerescences chorioretiennes. Ann Oculist 1961; 94: 385-96.

86 Winkler A. Retinitis pigmentosa sine pigmento auf dem einen und retinitis pigmentosa mit heterochromie-iridocyclitis auf dem anderen auge. Klin pigmentosa mit heterochromie-iridocyclitis

87 Vourre I, Saari M, Tilikainen I, Rasanen O. Fuchs' heterochromic cyclitis associated with retinitis pigmentosa: a family study. Can 7 Ophthalmol 1979; 14: $10-6$

88 Vadot E. Cyclite heterochromique de Fuchs post-traumatique. Bull Soc Ophtalmol Fr 1981; 81: 665-7.

89 Donoso LA, Eiferman RA, Magargal LE. Fuchs' heterochromic cyclitis associated with subclavian steal syndrome. Ann Ophthalmol 1981; 13: 1153-5.

90 Sugar HS, Banks TL. Fuchs' heterochromic cyclitis associated with facia hemiatrophy (sklerodermie en coupe de sabre). Am $\mathcal{F}$ Ophthalmol 1964; 57:
$627-32$.

91 Huber A, Kraus-Mackiw E. Heterochromiezyklitis Fuchs bei Moebius syndrom. Klin Monatsbl Augenheilkd 1981; 178: 182-5. 